\title{
I Encuentro Latinoamericano de Residentes de Odontopediatría
}

\author{
Resúmenes de Casos Clínicos
}

\author{
Coordinadores: Adriana Pistochini, María del Pilar Bernal, Comité Académico ALOP.
}

TRUQUE O, CAMPO SOTO MA, OCAMPO ARIAS I, OCHOA LEON A.

\section{MOLDEAMIENTO NASOALVEOLAR EN NIÑO CON LABIO Y PALADAR FISURADO UNILATERAL COMPLETO: REPORTE DE UN CASO CLINICO}

El labio y paladar hendido (LPH), es una malformación craneofacial que se desarrolla entre la sexta y decima semana de vida intrauterina. Es considerada una de las anomalías congénitas de mayor incidencia en la población mundial; y se origina debido a fallas en la fusión de los procesos palatinos, a la ausencia de unión entre el proceso maxilar y el proceso nasal medio. El moldeamiento pre-quirúrgico nasoalveolar (NAM), es un método no quirúrgico de remodelación de las encías, labios y fosas nasales antes de la cirugía para el cierre de la hendidura labio palatina, disminuyendo así la gravedad de la hendidura. En este artículo se reporta el caso de un paciente de género masculino de 43 días de nacido con diagnóstico de LPH unilateral completo izquierdo, remitido por el servicio del Cirugía Plástica del Hospital San Jose Centro al servicio de Odontología Pediátrica de la Universidad El Bosque; al cual se le trata con NAM dos meses y se logró: proyección de punta de nariz, remodelación de cartílagos nasales y aproximación de segmentos maxilares.

\section{NASOALVEOLAR MOLDING (NAM) IN CHILD WITH UNILATERAL CLEFT LIP AND PALATE: CASE REPORT}

Cleft Lip and Palate (CLP) is a craniofacial deformity that develops between the sixth and tenth week of intrauterine life. It is considered one of the highest incidences of birth defects in the world population; and it is caused due to the failure in the fusion of the palatal shelves, the absence of binding between the maxillary process and the middle nasal process. The pre-surgical nasoalveolar molding (NAM) is a non-surgical method of reshaping the gums, lips and nostrils before surgery to close the cleft lip and palate, reducing the severity of the cleft. This article describes the case of a male patient of 43 days old with a diagnosis of unilateral left cleft lip and palate, sent by the Plastic Surgery Service of Hospital San Jose Centro to the service of Pediatric Dentistry at the Universidad El Bosque; whom he was treated with NAM two months and achieved: nose tip projection, remodeling of nasal cartilage and approximation of maxillary segments. 


\section{CALAFELL REYES AA, MAGAÑA BARRIOS V, REJÓN PERAZA ME, SERRANO PIÑA R.}

\section{HETEROTAXIA VISCERAL ASPLENICA (HVA): REPORTE DE UN CASO Y SU MANEJO ESTOMATOLOGICO}

La Heterotaxia Visceral Asplénica (HVA), es un síndrome caracterizado por anormalidades relacionadas con la disposición interna de los órganos del cuerpo y comúnmente asociado a cardiopatías. Los órganos involucrados son las estructuras que están relacionadas entre sí: estómago, pulmones, corazón, hígado y vena cava inferior. Reporte del caso clínico: Paciente masculino de 10 años de edad con diagnóstico de HVA con cardiopatía asociada quién acude al servicio de Estomatología Pediátrica del Hospital Infantil de México Federico Gómez referido para protocolo de ingreso a quirófano. Intraoralmente se observan mucosas cianóticas, procesos cariosos y presencia de restos radiculares. El manejo estomatológico fue con previa profilaxis antiendocarditis (Amoxicilina $50 \mathrm{mg} / \mathrm{kg}$ ). El tratamiento consistió en terapia preventiva y restaurativa. Discusión: Todo paciente con cardiópata congénita debe ser tratado previa profilaxis antiendocarditis para prevenir alguna infección secundaria. El conocimiento de los medicamentos que esté tomando el paciente así como la hipersensibilidad hacia otros es de suma importancia. Se deben considerar el estado hemodinámico del paciente, así como el control radical de caries, con la finalidad de eliminar focos infecciosos que comprometan el estado general del paciente. Conclusiones: Los pacientes que presentan Cardiopatía Congénita son más susceptibles a desarrollar Endocarditis Infecciosa después del procedimiento odontológico.

\section{ASPLENIC VISCERAL HETEROTAXIA (AVH)}

Asplenic Visceral Heterotaxia (HVA) is a syndrome characterized by abnormalities related to the internal arrangement of the body's organs and commonly associated with heart disease. The bodies involved are the structures that are interrelated: stomach, lungs, and heart, liver and inferior vena cava. Clinical case report: Male patient 10 years old with a diagnosis of HVA associated with heart disease who presents to the Pediatric Stomatology Hospital Infantil de Mexico Federico Gomez referred for admission to the operating room protocol. Intraorally cyanotic mucous, carious processes and presence of root fragments were observed. The dental management was with previous antiendocarditis prophylaxis (amoxicillin $50 \mathrm{mg} / \mathrm{kg}$ ). Treatment consisted of preventive and restorative therapy. Reviews: All patients with congenital heart patient should be treated prior antiendocarditis prophylaxis to prevent any secondary infection. Knowledge of the medications the patient is taking and hypersensitivity to others is paramount. They should consider the patient's hemodynamic status and control the radical decay, in order to eliminate sources of infection that compromise the patient's general condition. Conclusions: Patients who have congenital heart disease are more susceptible to developing infectious endocarditis after dental procedure 


\section{REHABILITACIÓN BUCAL EN PACIENTE CON DIAGNÓSTICO DE ESTENOSIS ESOFÁGICA CONGÉNITA.}

Introducción: La Estenosis Esofágica Congénita (EEC) es el estrechamiento del esófago, que impide el paso normal del bolo alimenticio. La sintomatología inicial más importante es la regurgitación y vómito al introducir alimentos sólidos en la dieta. El diagnóstico se realiza mediante endoscopia y/o esofagograma. Reporte de caso: Masculino de 6 años 4 meses de edad con diagnóstico de EEC. La terapia preventiva se realizó con profilaxis dental y aplicación tópica de flúor, la terapia restaurativa se realizó con coronas de acero cromo y extracciones. Comentarios: A causa del reflujo grastroesofágico, la sialorrea, y/o las infecciones respiratorias recurrentes, es necesario monitorear el riesgo a caries, presencia de candidiasis y/o enfermedad periodontal, realizando tratamientos preventivos y de remineralización con el fin de disminuir el riesgo. Debido a que el tratamiento dental incluyó la extracción de múltiples órganos dentarios, es de suma importancia el uso de mantenedores de espacio y guías eruptivas para devolver la integridad biopsicosocial del paciente. Conclusiones: Una de las competencias que debe desarrollar el Odontopediátra es conocer el proceso de rehabilitación integral de los pacientes con anomalías congénitas para intervenir de manera oportuna en la atención multidisciplinaria del manejo de afecciones que comprometen al sistema estomatognático.

\section{ORAL REHABILITATION IN PATIENT WITH DIAGNOSIS OF CONGENITAL ESOPHAGEAL STENOSIS}

Introduction: The congenital esophageal stenosis (CES) is the narrowing of the esophagus, which prevents the normal passage of the bolus. The most important initial symptomatology is regurgitation and vomiting to introduce solid foods in the diet. The diagnosis is made by endoscopy or esophagram. Case report: Male 6 years 4 months of age with a diagnosis of CES. Restorative Therapy was performed with Steel/chrome crowns and extractions, preventive therapy was performed with topical application of fluoride and dental prophylaxis. Reviews: Because of gastroesophagic reflux, sialorrea or recurrent respiratory infections, it is necessary to monitor the risk of caries, candidiasis and/or periodontal disease, carrying out preventive and remineralization treatments in order to reduce the risk. Since dental treatment included extraction of multiple teeth organs is paramount use space maintainers and eruptive guides for correct oral rehabilitation of the patient. Conclusions: One of the skills which should develop the pediatric dentist is know the process of rehabilitation of patients with congenital anomalies to intervene in a timely manner in the multidisciplinary care of the management of disorders involving the stomatognathic system. 
ORTIZ ROSADO S, SERRANO PIÑA R, PINZÓN TE AL,AGUILAR AYALA F, CASTRO LINARES N.

\section{PLANEACIÓN Y TRATAMIENTO ORTOPÉDICO DE UN PACIENTE CON ESPECTRO FACIO-AURÍCULO-VERTEBRAL (EFAV)}

Introducción: Los síndromes craneofaciales cursan con anomalías de las estructuras del cráneo y la cara, de éstos, los que presentan comúnmente maloclusiones, se asocian con: a) Deficiencia mandibular, b) Prognatismo mandibular, c) Problemas de altura facial, d) Asimetría facial. La importancia de la prevención y el tratamiento temprano de estas anomalías, radica en evitar las recidivas y complicaciones que puedan aparecer de forma secundaria al síndrome logrando una mejor calidad de vida. Reporte del caso clínico: Paciente masculino de 5 años de la Clínica de la Maestría en Odontología Infantil de la FOUADY con diagnóstico base de EFAV. Clase II esqueletal por retrusión mandibular y protrusión maxilar con presencia de mordida abierta y hábito de proyección lingual. Se realiza planeación de tratamiento ortopédico y se coloca aparatología fija tipo Hass con restrictor de hábito lingual en arcada superior y aparatología tipo Hass con frente estético en arcada inferior. Comentarios: Los niños con EFAV presentan apertura oral limitada y/o maloclusión. La terapia ortopédica se puede iniciar con aparatos removibles o fijos. Conclusiones: El manejo de las necesidades de los pacientes con EFAV y otros síndromes craneofaciales, se traduce en un compromiso a largo plazo, e implica múltiples procedimientos que abarcan el período de crecimiento y desarrollo del niño.

\section{TREATMENT PLANNING FOR FACIO-AURICULO-VERTEBRAL SPECTRUM}

Introduction: Craniofacial syndromes present abnormalities of the structures in the head and face, the ones that commonly presents malocclusions are associated with: a)Mandibular deficiency, b) Mandibular prognathism, c) Problems of facial height, d)Facial asymmetry. The importance of prevention and early treatment of these anomalies, is to avoid recurrences and complications that might appear secondary to syndrome achieving a better life quality. Case report: 5 year old male patient of the Clinic of Pediatric Dentistry of FOUADY diagnosed with facio-auriculo-vertebral spectrum. Skeletal Class II malocclusion due to mandibular retrusion and maxillary protrusion with the presence of anterior open bite and tongue thrust habit. Orthopedic treatment planning is performed and appliances are placed, in the upper arch, haas expansion appliance with grid lingual spur and in the lower jaw, an anterior esthetic fixed appliance in combination with expander. Discussion: Children with EFAV have limited mouth opening and / or malocclusion. Orthopedic therapy should be initiated with removable or fixed appliances. Conclution: The management of patients with EFAV and other craniofacial syndromes, requires a long term treatment and following, and involves multiple procedures covering the period of growth and development of children. 


\section{CALLE-SÁNCHEZ MJ, MONTENEGRO-GUTIÉRREZ B.}

\section{ALTERNATIVA RESTAURATIVA A DIENTE DECIDUO ANTERIOR Y SUPERNUMERARIO FUSIONADOS.REPORTE DE CASO.}

Los dientes supernumerarios son definidos como cualquier diente adicional a la serie normal, son poco frecuentes en la dentición decidua; sin embargo, son considerados como una de las anomalías más significantes, más aún si se encuentran fusionados. La fusión dental es una anomalía que consiste en la unión de uno o más gérmenes dentarios adyacentes. La unión se da por medio del esmalte y la dentina dando como resultado un diente único. Se reporta el caso de una niña de 5 años de edad que acude a la Clínica de Odontopediatría de la Universidad Científica del Sur con problemas de autoestima y bullying de sus pares a causa de su pobre condición y apariencia dental. Al examen clínico extra oral se observa que la niña muestra sonrisa de labio cerrado. Al examen clínico intra oral se observan múltiples caries y en la zona anterosuperior lesiones de caries activas con compromiso pulpar y zonas de lesiones detenidas de color obscuro y un diente supernumerario fusionado a pieza 51 . Se realiza el tratamiento de pulpectomías en pieza 51 y supernumerario fusionado en una sesión y se procede a la rehabilitación estética mejorando la autoestima de la paciente después del tratamiento.

\section{RESTORATIVE ALTERNATIVE FOR A FUSED ANTERIOR DECIDUOUS TOOTH AND SUPERNUMMERARY TOOTH. CASE REPORT.}

Supernumerary teeth are defined as any additional tooth to the normal series. They are rare in deciduous dentition; however, they are considered one of the most significant anomalies, even more if they are fused. Dental fusion is an anomaly caused by the union of one or more adjacent tooth germs. Joint occurs through the enamel and dentin resulting in a single tooth. We report the case of a five years old girl who arrived to the Pediatric Dentistry Clinic of Universidad Cientifica del Sur with self-steem problems and bullying among friends because of her poor condition and dental appearance. Extra-oral clinical examination showed that the girl presented smile closed lip. By the other side, the intraoral clinical examination pointed out multiple cavities, inactive carious lesions at anterior upper teeth with evident pulpar lesion and areas of inactive lesions of dark color and a supernumerary tooth fused with 51 tooth. Pulpectomies in 51 tooth and supernumerary fused were done. Then, the aesthetic rehabilitation was completed improving the patient's self-esteem. 